\title{
The pathogenetic role of impaired fatty acid trapping by adipocytes in generating the pleiotropic features of hyperapoB
}

\author{
A.D. Sniderman ${ }^{1}$, K. Cianflone ${ }^{1}$, K. Frayn ${ }^{2}$ \\ ${ }^{1}$ McGill Unit for the Prevention of Cardiovascular Diseases, Montreal, Canada \\ ${ }^{2}$ Oxford Lipid Metabolism Group, Oxford, UK
}

HyperapoB is the commonest dyslipoproteinaemia associated with coronary disease $[1,2]$ and is characterized by an increased LDL particle number due to increased secretion of B100 lipoproteins by the liver [3]. The first feature of hyperapoB to be recognized was the elevated LDL particle number, many of which are smaller and denser than normal [4]. In reality, though, the metabolism of all the lipoprotein classes is demonstrably abnormal.

At the onset, however, it must be appreciated that hyperapoB is a phenotype, not a genotype, and there are multiple causes which produce increased hepatic secretion of B100 lipoprotein particles. The focus in this review, however, will be to outline how a reduced rate of fatty acid trapping by adipocytes can produce the pleiotropic features which characterize hyperapoB. At the end of this line of reasoning lies the conclusion that faults in fatty acid metabolism, not errors in the LDL pathway, are the commonest causes for the atherogenic dyslipoproteinaemias seen clinically.

The features of hyperapoB to be explicated are: 1 ) increased hepatic VLDL secretion; 2) increased LDL particle number; 3) smaller denser LDL particles; 4) reduced HDL cholesterol levels; 4) postprandial hyperlipaemia with accumulation of triglyceride-rich remnants; 5) elevated plasma non-esterified fatty acid levels (NEFA); and 6) insulin resistance.

Corresponding author: A. D. Sniderman, MD, McGill Unit for the Prevention of Cardiovascular Diseases, Royal Victoria Hospital, 687 Pine Avenue West, Montreal, Quebec, H3A 1A1 Canada

A bbreviations: NEFA, non-esterified fatty acids; LPL, lipoprotein lipase; ASP, acylation stimulating protein.
R egulation of the rate of fatty acid storage by adipocytes

The normal sequence involved in the uptake by adipocytes of fatty acids released from chylomicrons can be summarized as follows: chylomicrons attach to endothelial cells and the triglyceride within them is rapidly hydrolysed by lipoprotein lipase (LPL) [5]. The rate at which chylomicron triglyceride hydrolysis proceeds is determined by the number of LPL molecules involved and by the rate at which the NEFA which are generated are removed from the capillary microenvironment.

The NEFA which are liberated from the chylomicrons can enter the adipocyte to be trapped within it as triglyceride. Alternatively, they may bind to albumin, leave the capillary, and enter the general circulation. The proportion of NEFA released from chylomicrons which enter adipocytes is necessarily the reciprocal of the proportion which are not trapped by adipocytes and which then leave the microenvironment. Under normal circumstance, the proportions are about equal [6]. The proportion of NEFA which are trapped by adipocytes is determined by their rate of triglyceride synthesis, the major determinant of which is the acylation stimulating protein (ASP) pathway [7].

ASP is the product of the ASP pathway and, as just noted, is the major determinant of the rate of triglyceride synthesis within adipocytes. The major features of the pathway are described elsewhere [8]. In brief, human adipocytes synthesize and secrete the three proteins of the alternate complement pathway which interact to form a 77 amino terminal fragment of $\mathrm{C} 3$, the terminal arginine of which is removed by carboxypeptidases to produce ASP. ASP then interacts specifically with a receptor in the cell membrane [9] to activate a protein kinase $\mathrm{C}$ signal transduction pathway [10] which results in increased activity of 
diacylglycerol acyltransferase [11], the last enzyme involved in the synthesis of a triglyceride molecule, and increased specific membrane transport of glucose $[12,13]$. The latter effect is independent of, but additive to, that of insulin $[12,13]$. As adipocytes differentiate and become larger, they become more competent to generate ASP and to respond to ASP $[14,15]$. Both in vivo and in vitro evidence has established that chylomicrons stimulate the formation of ASP $[16,17]$. The ASP pathway is, therefore, a unique regulatory metabolic system. The adipocyte produces the precursors and responds to the product. Moreover, the pathway in the adipocyte is activated by its physiologic target, the chylomicron, the net result being intricate and elegant metabolic regulation within the microenvironment.

\section{Consequences of an impaired A SP pathway}

Reduced functioning of the ASP pathway will produce a broad series of consequences. If NEFA concentration in the adipose tissue microenvironment rises due to decreased trapping efficiency by the adipocyte, excess NEFA will be delivered to the liver, LPL activity will be inhibited by product inhibition [18], and triglyceride-rich chylomicron particles will be prematurely detached from the endothelial surface [19]. The reduced rate of triglyceride lipolysis by LPL and the generation and release into plasma of triglyceride-rich chylomicron remnants are both responsible for the delayed postprandial plasma triglyceride clearance that is characteristic of patients with hyperapoB [20].

In vitro and in vivo studies have established that increased delivery of NEFA or uptake of triglyceriderich remnants to the liver will cause the secretion rate of VLDL particles to increase [21, 22]. An increased secretion rate of VLDL will result in the increased generation of LDL particles. Many of these LDL particles will be smaller and denser than normal because of increased core lipid exchanges between VLDL and LDL [23]. These core lipid exchanges are further facilitated by higher ambient NEFA levels present in these patients. Accelerated core lipid exchanges have another consequence, namely the reduced HDL cholesterol that is also frequently present. Finally, abnormal NEFA metabolism has also been postulated to be the basis for the insulin resistance [24] which is also so common in this category of patient.

\section{D efective A SP receptor function and omental obesity as causes of hyperapoB}

The brief outline above sets out how a single, critically sited, metabolic defect - reduced trapping of fatty acids by adipocytes - could be responsible for all the lipoprotein manifestations of hyperapoB. Two common causes of the syndrome are ASP receptor defective hyperapoB and omental obesity. Studies with cultured human skin fibroblasts have shown that the effects of ASP on triglyceride synthesis are due to specific binding to a cell membrane receptor and that this receptor is deficient or defective in an important proportion of patients with hyperapoB [9]. Consequently, the maximal rate of adipocyte triglyceride synthesis - that is to say, fatty acid trapping - is reduced. Omental adipocytes are less effective than subcutaneous adipocytes at synthesizing triglycerides $[25,26]$ and therefore are also less effective at trapping fatty acids. Whatever the mechanism responsible, omental adipocytes - or more properly, any adipocyte with reduced triglyceride synthetic capacity - will produce the biologic consequences listed above when exposed to a high fatty acid intake.

\section{References}

1. Sniderman AD, Shapiro S, Marpole DG, Skinner BF, Teng B, Kwiterovich PO (1980) Association of coronary atherosclerosis with hyperapobetalipoproteinemia [increased protein but normal cholesterol levels in human plasma low-density (B) lipoproteins]. Proc Natl Acad Sci USA 77(1):604-608

2. Lamarche B, Despres JP, Moorjani S, Cantin B, Dagenais GR, Lupien PJ (1995) Prevalence of dyslipidemic phenotypes in ischemic heart disease (prospective results form the Quebec Cardiovascular Study). Am J Cardiol 75: 1189-1195

3. Teng B, Sniderman AD, Soutar AK, Thompson GR (1986) Metabolic basis of hyperapobetalipoproteinemia: turnover of apolipoprotein B in low-density lipoprotein and its precursors and subfractions compared with normal and familial hypercholesterolemia. J Clin Invest 77(3):663-672

4. Teng B, Thompson GR, Sniderman AD, Forte TM, Krauss RM, Kwiterovich PO Jr (1983) Composition and distribution of low-density lipoprotein fractions in hyperapobetalipoproteinemia, normolipidemia and familial hypercholesterolemia. Proc Natl Acad Sci USA 80(21):6662-6666

5. Goldberg IJ (1996) Lipoprotein lipase and lipolysis: central roles in lipoprotein metabolism and atherogenesis. J Lipid Res 37: 693-707

6. Frayn KN, Shadid S, Hamiani R et al. (1994) Regulation of fatty acid movement in human adipose tissue in the postabsorptive-to-postprandial transition. Am J Physiol 266: E306-E317

7. Baldo A, Sniderman AD, St-Luce S et al. (1993) The adipsin-acylation stimulating protein system and regulation of intracellular triglyceride synthesis. J Clin Invest 92(3): 1543-1557

8. Cianflone K, Maslowska M, Sniderman AD (1995) The acylation stimulating protein-adipsin system. Symposium proceeding. Int J Obesity (19):S34-S38

9. Cianflone K, Maslowska M, Sniderman AD (1990) Impaired response of fibroblasts in patients with hyperapobetalipoproteinemia to acylation stimulating protein. J Clin Invest 85(3):722-730

10. Baldo A, Sniderman AD, Yasruel Z, Cianflone K (1995) The signal transduction pathway of acylation stimulating 
protein: involvement of protein kinase C. J Lipid Res (36):1415-1426

11. Yasruel Z, Cianflone K, Sniderman AD, Rosenbloom M, Walsh M, Rodriguez MA (1991) Effect of acylation stimulating protein on the triacylglycerol synthetic pathway of human adipose tissue. Lipids 26(7):495-499

12. Germinario R, Sniderman AD, Manuel S, Pratt S, Baldo A, Cianflone K (1993) Coordinate regulation of triacylglycerol synthesis and glucose transport by acylation stimulating protein. Metabolism 40(5):574-580

13. Tao Y, Cianflone K, Sniderman AD, Colby-Germinario SP, Germinario RJ (1996) Acylation stimulating protein (ASP) regulates glucose transport in the rat L6 muscle cell line. Biochim Biophys Acta 1344(3): 221-229

14. Cianflone K, Roncari DAK, Maslowska M, Baldo A, Forden J, Sniderman AD (1994) The adipsin-acylation stimulating protein system in human adipocytes: regulation of triacylglycerol synthesis. Biochemistry 33(14):9489-9495

15. Cianflone K, Maslowska M (1995) Differentiation induced production of ASP in human adipocytes. Eur J Clin Invest 25: $817-825$

16. Cianflone K, Vu H, Walsh M, Baldo A, Sniderman AD (1989) Metabolic response of acylation stimulating protein to an oral fat load. J Lipid Res 30(11):1727-1733

17. Maslowska M, Scantlebury T, Germinario R, Cianflone K (1993) Acute in vitro production of ASP in differentiated human adipocytes. J Lipid Res 34(2):219-228

18. Bengtsson G, Olivecrona T (1980) Lipoprotein lipase. Mechanism of product inhibition. Eur J Biochem 106: $557-562$
19. Saxena U, Witte LD, Goldberg IJ (1989) Release of endothelial cell lipoprotein lipase by plasma lipoproteins and free fatty acids. J Biol Chem 264(8):4349-4355

20. Genest J, Sniderman AD, Cianflone K et al. (1986) Hyperapobetalipoproteinemia: plasma lipoprotein responses to oral fat load. Arterlosclerosis 6(3):297-304

21. Sniderman AD, Brown BG, Stewart FF, Cianflone K (1992) From familial combined hyperlipidemia to hyperapoB: unravelling overproduction of hepatic apoB lipoproteins. Current Opinion in Lipidology 3(2):137-142

22. Sniderman AD, Cianflone K (1993) Substrate delivery as a determinant of hepatic apoB secretion. Arterio Thromb 13(5):629-636

23. Sniderman AD, Thomas D, Marpole DG, Teng B (1978) Low-density lipoprotein: a metabolic pathway for return of cholesterol to the splanchnic bed. J Clin Invest 61: 867873

24. Frayn KN, Williams CM, Arner P (1996) Are increased plasma non-esterified fatty acid concentrations a risk marker for coronary heart disease and other chronic disease? Clinical Science 90: 243-253

25. Maslowska MH, Sniderman AD, MacLean LD, Cianflone K (1993) Regional differences in triacylglycerol synthesis in adipose tissue. J Lipid Res 34(2):219-228

26. Edens NK, Fired SK, Kral JG, Hirsch J, Leibel RL (1993) In vitro lipid synthesis in human adipose from three abdominal sites. Am J Physiol 265(28):E374-E379 